\title{
PartyPolitics
}

\section{The far-right, immigrants, and the prospects of democracy satisfaction in Europe}

\author{
Aida Just \\ Department of Political Science and Public Administration, Bilkent University, Ankara, Turkey
}

\begin{abstract}
This paper examines the consequences of the far-right in shaping foreign-born immigrants' satisfaction with the way democracy works in their host country. It posits that while electorally successful far-right parties undermine democracy satisfaction, the magnitude of this effect is not uniform across all first-generation immigrants. Instead, it depends on newcomers' citizenship status in their adopted homeland. The analyses using individual-level data collected as part of the five-round European Social Survey (ESS) 2002-2012 in 16 West European democracies reveal that the electoral strength of far-right parties in a form of vote and seat shares won in national elections is indeed powerfully linked to democracy satisfaction among foreign-born individuals. However, this relationship is limited to foreign-born non-citizens, as we have no evidence that far-right parties influence democracy attitudes among foreign-born individuals who have acquired citizenship in their adopted homeland.
\end{abstract}

\section{Keywords}

democracy satisfaction, far-right parties, immigrants, political legitimacy

With the growing size and diversity of immigrant populations in western democracies, the political integration of newcomers into their host societies has become of central importance to many academic and policy debates (e.g. Hochschild and Mollenkopf, 2009; Joppke, 2007a, 2007b; Wright and Bloemraad, 2012). One key concern has been whether immigrants are sufficiently committed to democratic governance, whether they evaluate political systems in countries that receive them in the same way as native populations, and whether granting immigrants citizenship (or failing to do so) may affect the stability and quality of democratic life. These questions have become increasingly more salient over time, turning immigration into the most polarizing issue of electoral politics in Western Europe since the 1990s (Kriesi et al., 2008; see also Alonso and Claro da Fonseca, 2012).

This study seeks to contribute to existing debates on immigration by focusing on democracy satisfaction among foreign-born individuals in Western Europe. ${ }^{1}$ Low levels of system support have been long assumed to pose grave problems for democracies (Hetherington, 1998; Lipset, 1959; Powell, 1982, 1986; see also Dalton, 2004; Pharr and Putnam, 2000), encouraging researchers to devote considerable attention to how people come to form their political legitimacy beliefs. These opinions have been shown to be influenced by what political systems are and do - their institutions, processes, and performance - but also people's expectations about how these should function. Specifically, scholars found that people express more favorable views about the political systems that generate more positive outcomes (economic, political, and the like), and that do so more fairly (Tyler, 1990). Individual expectations matter as well, as democracy satisfaction can be lower among individuals who want more democracy, not less (e.g. Norris, 1999, 2011).

While much is known about legitimacy beliefs of native populations, systematic research on such attitudes among immigrants remains limited. This is surprising given that many newcomers, particularly in recent decades, arrive from countries with little democratic experience. Moreover,

Paper submitted 5 October 2014; accepted for publication 12 August 2015

\section{Corresponding author:}

Aida Just, Department of Political Science and Public Administration, Bilkent University, 06800 Bilkent, Ankara, Turkey.

Email: aidap@bilkent.edu.tr 
foreigners are often said to have dual allegiances to origin and destination countries, potentially diluting their commitment to their new homeland and its democratic governance. Existing research has acknowledged that standard explanations are helpful but insufficient in explaining immigrants' political preferences as well as understanding how and why they choose to engage in politics (e.g. Cho et al., 2006; Ramakrishnan, 2005). Since foreigners were socialized in political systems that differ from the ones they subsequently inhabit, possess varied rights and entitlements depending on their legal status, and are exposed to different socio-cultural, political, and economic environments in their host countries, explaining immigrants' attitudes and behavior requires accounting for these experiences.

Below, we develop a model of immigrants' satisfaction with the way democracy works in their host country that takes into consideration such immigrant-specific experiences, while controlling for traditional predictors of system support. Our model highlights the importance of far-right parties and immigrants' political incorporation into their host country via citizenship. Specifically, we posit that far-right parties contribute negatively to democracy satisfaction among foreign-born individuals. However, the magnitude of this relationship depends on whether a foreign-born individual has acquired citizenship in one's adopted homeland or not. The analyses using individuallevel data collected as part of the five-round European Social Survey (ESS) 2002-2012 in 16 West European democracies confirm these expectations. We find that the strength of far-right parties - whether measured in terms of vote or seat shares won in national elections - is powerfully linked to democracy satisfaction among first-generation immigrants. However, this relationship is limited to newcomers who have not been naturalized in their host country, as the results reveal no evidence of such a relationship among foreign-born individuals who hold citizenship of their adopted homeland.

This study contributes to existing research in several ways. First, given that the quality and stability of democratic life in Europe increasingly depends on foreigners, whose numbers have grown significantly over the last few decades, our analysis adds to previous studies by focusing on democracy satisfaction of foreign-born individuals rather than natives, and by systematically analyzing the determinants of these attitudes. Second, our model highlights the critical, but complex, role that far-right parties play in shaping these attitudes. In doing so, we extend scholarship on the far-right by considering its electoral success as a key independent rather than dependent variable, and contribute to an expanding body of scholarship on the consequences of the far-right for West European politics. ${ }^{2}$ Third, our study adds to research on citizenship by testing whether formal membership in a polity continues to exert an impact on people's political views in contemporary democracies where differences in legal rights between citizens and non-citizens have been significantly reduced in recent decades (Hollifield, 1992; Jacobson, 1996; Soysal, 1994). Finally, we contribute to a growing set of systematic cross-national studies on immigrants' political attitudes and behavior that test arguments using a wide range of countries with diverse immigrant populations.

\section{The far-right, threat perceptions, and immigrants' legitimacy beliefs}

It has long been known that people's political attitudes and behavior are affected by their perceptions of what others think or do (e.g. Cooley, 1956; Mutz, 1998). Individuals constantly (and to a large extent unconsciously) scan their environment to assess which opinions might become favored by the majority and which ones might lead to social isolation (e.g. Scheufele and Moy, 2000). Moreover, those belonging to subordinate or less powerful groups have been found to be particularly attuned to their surroundings, paying attention to shifts even in the affective and nonverbal tone of dominant group members (Frable, 1997; Hall and Briton, 1993; Oyserman and Swim, 2001). Since immigrants commonly perceive themselves to be in an inferior position due to their outsider status in their host societies, they should be highly sensitive to their socio-political environment, especially with respect to natives' actions that have direct consequences for newcomers in their adopted homeland.

We argue that an important aspect of this socio-political context is the strength of far-right parties in national elections. Far-right parties in Western Europe have often sought political power by campaigning explicitly (although not always exclusively) on the basis of anti-immigrant appeals (Ivarsflaten, 2008; Joppke, 2007a; Messina, 2007; Mudde, 2007; Zaslove, 2004). They usually reject immigration as an invasion of foreign customs and traditions that weaken natives' cultural identity, and also as a threat to national security, employment, and social welfare. And although far-right parties are not single-issue parties (e.g. Carter, 2005; Gibson, 2002; Mudde, 2000), opposition towards immigration has been found to be the only issue that unites all successful far-right parties in Western Europe (Ivarsflaten, 2008). ${ }^{3}$ Moreover, some scholars argue that far-right parties have played an important role in adopting stricter immigration and immigrant integration policies, particularly with respect to migrants' naturalization and cultural rights, although the precise mechanism via which they have done so remains a matter of debate (Alonso and Claro da Fonseca, 2012; Koopmans et al., 2012: 1234; Schain, 2006; Zaslove, 2004; but see Akkerman, 2012; Bale, 2008).

Given the focus of far-right parties on anti-immigrant policies in established democracies, it should not be surprising that foreign-born individuals in these countries view far-right parties as an important source of threat. A 
number of studies demonstrate that perceptions of threat among immigrants have consequences for their political behavior. They show, for example, that anti-immigrant legislation in the US in the mid-1990s, which sought to restrict immigrants' access to welfare benefits, increased voting turnout among first- and second-generation immigrants (Pantoja et al., 2001; Ramakrishnan, 2005, especially Chapter 6; Ramakrishnan and Espenshade, 2001). Similarly, perceptions of threat associated with the Patriot Act legislation and incidents of racially motivated discrimination and violence resulted in higher voter registration among more educated Arab immigrants (Cho et al., 2006). Moreover, research shows that immigrants mobilized politically and rallied fiercely for their enfranchisement in response to growing electoral strength of the far-right in Belgium (Jacobs, 1999). Taken together, these studies suggest that perceptions of threat among immigrants contribute positively to their political engagement, and that immigrants' dissatisfaction with the political status quo and the desire to change it fuel this relationship.

If immigrants indeed respond to perceived threat to their rights and freedoms by adopting more negative views about the political status quo in their host society, then the strength of anti-immigrant far-right parties in national elections should play a considerable role in shaping their satisfaction with the functioning of democracy. Since policies related to immigrant admission and integration continue to be decided largely at the level of nation-states (as opposed to sub-national regions or the EU), ${ }^{4}$ it should not be surprising that newcomers may see the success of farright parties in national elections as a source of concern that their rights and freedoms will be restricted in the newly elected parliament. ${ }^{5}$ Moreover, high shares of votes/seats secured by far-right parties may result in further mobilization of anti-immigrant sentiment among natives. This is because, according to the spiral of silence theory (NoelleNeumann, 1974, 1993), those who hold unpopular (in this case, xenophobic) views but were previously afraid to express them may become more vocal, as they realize that they are no longer part of a small minority and have gained access to important policy making institutions. Hence, the success of far-right parties represents a double threat to immigrants: it may lead not only to more restrictive immigration and immigrant integration policies in the short run, but also to a more hostile socio-political environment towards immigrants in the long run.

In short, by making immigrants feel more threatened and unwanted in their host society, the electoral success of far-right parties should motivate foreign-born individuals to adopt more negative opinions about the political status quo in their host country. Conversely, where far-right parties receive few votes and seats in national elections, and therefore remain weak or absent from the electoral arena and policy-making institutions, immigrants should be more likely to see themselves as part of their host society and having a stake in its political system. As a consequence, foreign-born individuals in countries where farright parties fare poorly at the voting booth should express more positive opinions about the functioning of democratic governance in their adopted homeland. Hence, we hypothesize that higher vote or seat shares received by the far-right in national elections should result in lower levels of democracy satisfaction among foreign-born individuals (Hypothesis 1).

\section{Contingent effects of the far-right: The role of citizenship}

In addition to understanding the effect of the far-right on first-generation immigrants' legitimacy beliefs, we are interested in whether this impact is uniform across all foreign-born individuals. Specifically, we ask whether formally incorporating newcomers into the polity of their host country influences how immigrants respond to the electoral success of far-right parties when forming their opinions about their host country's democratic governance. We argue that citizenship moderates the relationship between far-right vote/seat shares and support for the political system among foreign-born individuals: specifically, while the fortunes of the far-right in national elections can be expected to reduce democracy satisfaction among all first-generation immigrants, this negative relationship should be weaker (or insignificant) among newcomers who have acquired citizenship in their adopted homeland.

We base these expectations on several insights from previous research. By formally distinguishing between insiders and outsiders, citizenship is known to have an instrumental and symbolic value to individuals who hold it (Bauböck, 2007; Bloemraad et al., 2008). Instrumentally, it provides people with formal protections and material benefits (e.g. the right to vote in national elections, wider employment opportunities and welfare benefits, visa-free travel, and protection against deportation), while symbolically citizenship is usually seen as an expression of kinship or psychological attachment to a country. Both aspects of citizenship lead us to expect that the far-right should exert a stronger impact on legitimacy beliefs among foreign-born non-citizens than among foreign-born citizens. To put it simply, because citizenship provides important rights, protections, and entitlements, the electoral performance of the far-right should appear less consequential to the situation of immigrants who have naturalized in their country of residence. In contrast, individuals without citizenship are more likely to feel personally threatened by powerful far-right parties. Hence, instrumental considerations associated with citizenship should alleviate threat perceptions among immigrants, and consequently weaken the impact that the electoral fortunes of the far-right may have for newcomers' democracy satisfaction in their country of residence. 
Citizenship status is important also in several other ways. Without the legal right to vote in national elections, non-citizen immigrants cannot counteract the far-right by voting for other parties or casting blank votes. Nor can they expect support from or be defended by other parties, as politicians seeking public office at the national level rarely have incentives to appeal to individuals who do not have the right to vote. Hence, a sense of threat along with disenfranchisement in the presence of strong far-right parties should encourage foreign-born individuals to adopt more negative attitudes towards the functioning of the political system in their host country if they are non-citizens.

Finally, citizenship may moderate the relationship between the electoral strength of the far-right and democracy satisfaction among foreign-born individuals also for symbolic reasons. From this perspective, citizenship acquisition is an expression of kinship or psychological attachment to one's adopted homeland that encourages immigrants to consider their new country as their own. ${ }^{6}$ Previous studies reveal that citizenship motivates foreigners to pay more attention to the realities of their adopted country when forming attitudes towards policy issues and political institutions (e.g. Just and Anderson, 2015; Röder and Mühlau, 2011). This research shows, for example, that foreigners who have acquired citizenship of their host country are less likely to support immigration than foreign-born non-citizens, particularly when they are dissatisfied with the macro-economy in their host country. Such socio-tropic orientations along with weaker support for immigration among foreign-born citizens may encourage foreign-born individuals who have acquired citizenship in their host country to see the success of the far-right in a less negative light compared to those who have not been naturalized.

Taken together, these studies suggest that citizenship should weaken the negative effect of the far-right on democracy satisfaction among foreign-born individuals. At the same time, however, there are reasons to suspect that citizenship may not completely eliminate this effect. This is because first-generation immigrants often hold dual allegiances (e.g. Just and Anderson, 2015; Pérez, 2014; Simon et al., 2015), that is, an attachment to their host country but also a continued identification with other immigrants or co-ethnics who, like themselves, have gone through the experience of migrating and settling in a new country. As a consequence, they know that migration can be a difficult process of physical and psychological uprooting and relocation, which often requires considerable efforts in adjusting to a new environment as well as learning how to cope with the consequences of being an outsider and being different in one's adopted homeland. ${ }^{7}$ Hence, kinship and solidarity with other migrants may encourage foreign-born individuals to react to the far-right electoral fortunes even when the host country's citizenship shields them from the reach of anti-immigrant far-right policies.
In short, we expect that the electoral strength of the farright interacts with citizenship in shaping immigrants' legitimacy beliefs. Specifically, while the success of the far-right at the voting booth is likely to be negatively linked to democracy satisfaction among all foreign-born individuals, this negative relationship should be particularly pronounced among those who are non-citizens. If our expectations are correct, the analyses should reveal negative and statistically significant coefficients of national vote/seat shares of far-right parties, but a positive (and statistically significant) coefficient of the interaction between citizenship and far-right party strength in shaping immigrants' satisfaction with the way democracy works in their host country. Hence, our second hypothesis is that the negative effect of vote/seat shares received by far-right parties in national elections should be less pronounced (or insignificant) among foreign-born individuals who hold citizenship of their host country (Hypothesis 2).

\section{Data and analysis}

We test our expectations using individual-level data collected as part of the five-wave European Social Survey (ESS) 2002-2012. Widely recognized for its high methodological standards in cross-national survey design and data collection (Kittilson, 2009), ${ }^{8}$ this project is the only set of cross-national surveys that ask questions related to people's citizenship, foreign-born status, origin country, and duration of stay in the host country, alongside the standard question whether respondents are satisfied with the way democracy works in their country of residence. The relevant survey items and macro-level indicators were available for 16 established democracies in Western Europe: Austria, Belgium, Denmark, Finland, France, Germany, Greece, Ireland, Italy, the Netherlands, Norway, Portugal, Spain, Sweden, Switzerland, and the United Kingdom.

\section{Dependent variable}

To capture individuals' support for the political system, we rely on a commonly used measure of democracy satisfaction. The relevant survey item asked respondents: "On the whole, how satisfied are you with the way democracy works in [country]?" Responses were coded on a scale from 0 to 10 , with higher values denoting more satisfaction. ${ }^{9}$ While not without critics, it is generally acknowledged as an indicator of people's evaluations of regime performance rather than democracy as an ideal (Anderson et al., 2005: 41; Fuchs et al., 1995: 328; Klingemann, 1999; Linde and Ekman, 2003; Norris, 1999), and captures people's support for the political system at a low level of generalization (Anderson and Guillory, 1997; Fuchs et al., 1995: 330). 


\section{Independent variables}

To identify foreign-born respondents and to distinguish between citizens and noncitizens among them, we relied on two ESS questions "Were you born in [country]"? and "Are you a citizen of [country]?" Both are dichotomous, with 1 indicating a positive response, and zero a negative one. Pooling the data across countries generates a sample of 11,548 foreign-born respondents ( $7.90 \%$ of all surveyed individuals); ${ }^{10}$ of these, $48.73 \%$ are citizens and $51.27 \%$ are non-citizens. ${ }^{11}$

To test whether far-right parties reduce democracy satisfaction among foreign-born individuals, and whether citizenship plays a role in moderating this relationship, we rely on McLaren's (2012) classification of far-right parties with anti-immigrant orientation. McLaren selected parties that expressed opposition to immigration as one of their main policy positions in national elections preceding the fielding of the ESS questionnaire (McLaren, 2012: 235). ${ }^{12}$ To verify whether far-right parties on our list are indeed more anti-immigrant than other parties, we used Benoit and Laver's (2006) expert surveys on party placement with respect to the issue of immigration. ${ }^{13}$ Specifically, experts were asked to place political parties in their country on a scale from 1 to 20 , where 1 indicates that a party favours policies designed to help asylum seekers and immigrants to integrate into [country's] society, and 20 shows that a party favours policies designed to help asylum seekers and immigrants return to their country of origin. This means that higher values on this variable denote more hostility towards immigration. The salience variable also ranges from 1 to 20, with higher values indicating that an issue is more salient to a party.

Table 1 reports the mean values of party placement with respect to both salience and position on immigration among our far-right parties in comparison to other parties. It reveals that far-right parties are consistently more antiimmigrant than other parties, and this is true for all countries in our sample. ${ }^{14}$ The average score of far-right party position (on a scale from 1 to 20 ) on immigration is 19.10 , whereas the respective mean for all other parties is 9.07 - a difference of more than 10 points. The results with respect to issue salience indicate that while other parties are not indifferent to immigration, the issue is clearly more salient to far-right parties than it is to other parties: the mean scores are 18.86 and 13.44, respectively. Taken together, the results confirm that far-right parties included in our analyses are indeed more hostile towards immigrants and care about immigration more than other parties.

We employ two measures to capture far-right parties' electoral strength: their vote and seat shares in national elections prior to a respondent's ESS interview. Far-right vote shares in our sample of countries range from $0 \%$ (e.g. Spain) to $29.4 \%$ (Switzerland), with the mean value of $5.48 \%$. Seat shares similarly range from $0 \%$ in several countries (e.g. UK, Germany, and Ireland) to $31 \%$ in Switzerland, with the mean value of $4.48 \%$. (For more detailed information on these variables, see the Appendix).

\section{Control variables}

Our empirical estimations include a number of control variables previously shown to be important determinants of political system support. At the micro-level, we take into account whether a respondent feels close to a party in government, as those who endorsed ruling parties have been found to be more satisfied with democracy (Anderson and Guillory, 1997; Anderson et al., 2005; Ginsberg and Weissberg, 1978; Nadeau and Blais, 1993; Norris, 1999). Moreover, since left-wing views and more extreme ideological positions are generally linked to more openness to change and more critical opinions about the political system (Anderson and Singer, 2008; Anderson et al., 2005: Ch. 5; Riker, 1982), our models take into account the respondent's left-right self-placement and its distance from his or her country's left-right median in each survey round.

To identify individuals with greater incentives to maintain the socio-political status quo, we use standard demographic variables (age, gender, marital status), indicators of people's socio-economic status (income, education, and manual skills) (Almond and Verba, 1963; Anderson et al., 2005: 20), and perceptions of discrimination against one's group (Michelson, 2001, 2003; Röder and Mühlau, 2011). Moreover, since better economic performance tends to strengthen system legitimacy (e.g. Anderson et al., 2005: 148; Clarke et al., 1993), our empirical estimations include respondents' evaluations of the macro-economy in their host country.

Beside standard predictors of legitimacy beliefs, we control for immigrant-specific experiences in both sending and receiving countries. To capture political socialization before migration, we include a polity score of immigrants' countries of origin at the time of arrival. We expect that immigrants from less democratic countries are more satisfied with democracy in their adopted homeland because they are more likely to appreciate political freedoms and opportunities to influence politics that they did not have in their home country. Moreover, since socialization in less democratic regimes means less familiarity with democratic governance (Ramakrishnan, 2005: 91; White et al., 2008), and thus lower expectations from the political system of their host country (Maxwell, 2010; Röder and Mühlau, 2011, 2012), immigrants from such regimes may have less critical attitudes of the way democracy works than foreigners from more democratic countries. Similarly, more recent arrivals can be expected to be more satisfied with the political system than foreigners who arrived to their destination a long time ago (Maxwell, 2010; Röder and Mühlau, 2011, 2012). Finally, since a respondent's ability to follow the host country's politics is enhanced by linguistic skills, we 
Table I. Salience and position on immigration among far-right parties compared to other parties in 16 West European democracies.

\begin{tabular}{lccrrr}
\hline & \multicolumn{2}{c}{ Far-right Parties } & & \multicolumn{2}{c}{ Other Parties } \\
\cline { 2 - 3 } \cline { 5 - 6 } Country & Position on immigration & Salience of immigration & Position on immigration & Salience of immigration \\
\hline Austria & 18.50 & 18.00 & 8.75 & 14.35 \\
Belgium & 19.52 & 19.49 & 9.74 & 14.79 \\
Denmark & 19.34 & 19.40 & 10.57 & 15.87 \\
Finland & 18.84 & 18.26 & 8.67 & 11.47 \\
France & 19.26 & 19.17 & 10.19 & 13.53 \\
Germany & 19.23 & 18.92 & 12.06 & 15.55 \\
Greece & - & - & 8.97 & 13.49 \\
Ireland & - & - & 10.46 & 11.44 \\
Italy & 17.63 & 17.73 & 8.88 & 14.15 \\
The Netherlands & 18.32 & 18.75 & 9.65 & 13.35 \\
Norway & 19.09 & 18.52 & 7.16 & 12.47 \\
Portugal & - & - & 7.65 & 14.38 \\
Spain & - & - & 10.58 & 13.55 \\
Sweden & - & - & 7.06 & 12.30 \\
Switzerland & 19.24 & 18.92 & 10.99 & 13.98 \\
UK & - & - & 9.05 & 1.73 \\
Average & 19.10 & 18.86 & 9.07 & 13.44 \\
\hline
\end{tabular}

Source: Calculations based on Benoit and Laver (2006) data.

control for whether a respondent speaks the host country's official language at home.

Another potentially relevant aspect of a foreigner's background is whether one is a third-country national or a citizen of another European Union country. Given that the EU member states operate within the multi-level structure of political institutions, foreign-born individuals who are nationals of other EU countries may not only be more familiar with the political processes in their host countries, but also enjoy more extensive political rights and socioeconomic entitlements than third-country nationals (Koopmans et al., 2012: 1209). While these rights and entitlements should generally enhance democracy satisfaction, familiarity with political processes and higher expectations may encourage foreign-born EU citizens to adopt more critical opinions of the political systems in their countries of residence compared to third-country nationals. Our models therefore control for this variable, although its overall effect is not easy to predict.

To capture policy environment designed to integrate immigrants in their host society at the macro-level, we rely on two measures: Banting and Kymlicka's (2006) index of immigrant multiculturalism policies and an indicator of immigrants' political participation rights from the Migrant Integration Policy Index (MIPEX) database (Niessen et al., 2007). Furthermore, since immigrants have been found to be sensitive to sub-national opinion climates of natives (e.g. Maxwell, 2013), we include measures of regional satisfaction with democracy among natives ${ }^{15}$ and regional opinion climate towards immigrants among natives. Finally, because our analyses are based on the cumulative five-round survey data, we include dummy variables for ESS rounds, using the first round as the reference category for other rounds. (Details on survey questions and coding for all measures are reported in the Appendix).

\section{Analysis and results}

Our model of democracy satisfaction among foreign-born immigrants combines information collected at the level of countries and individuals. This means that our dataset has a multi-level structure that may present a number of statistical problems, including non-constant variance, clustering, and incorrect standard errors (e.g. Snijders and Bosker, 1999; Steenbergen and Jones, 2002). The empirical estimations presented below therefore rely on multi-level models where one unit of analysis (foreign-born individuals) is nested within another unit of analysis (country-rounds). ${ }^{16}$ The mixed-effects multi-level models include random intercepts for both immigrants' host and origin countries (to allow for cross-country variability in democracy satisfaction levels), ${ }^{17}$ and random slopes for the citizenship variable (to allow for cross-country variability in the magnitude of citizenship coefficient).

The results reported in Table 2 reveal that there is indeed a negative and statistically significant relationship between far-right party strength in national legislative elections and democracy satisfaction among foreign-born individuals. Hence, in line with our expectations, the electoral fortunes of the far-right in a form of vote or seat shares are negatively linked to immigrants' support for the political system in their host country. However, the results of our interaction 


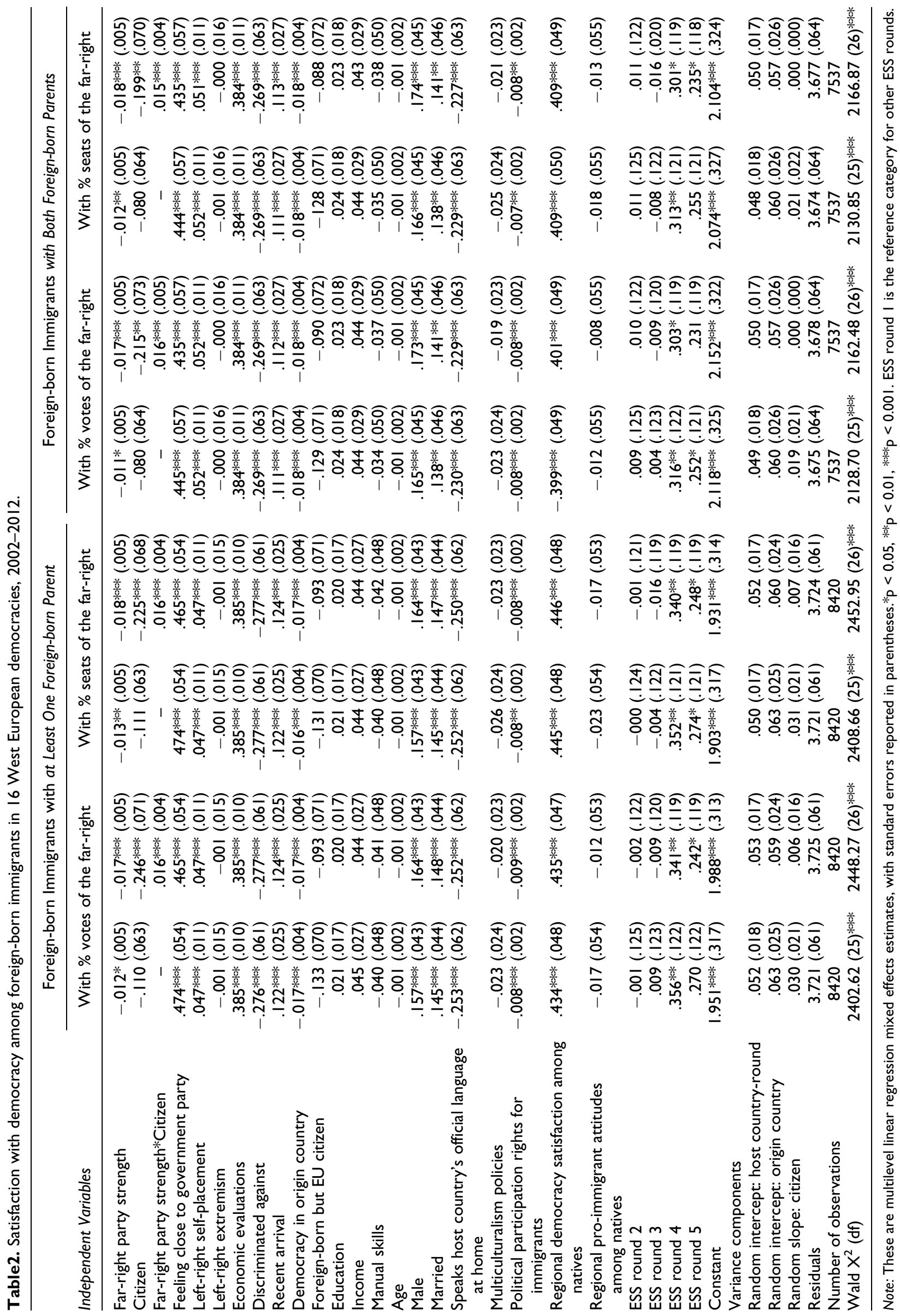


models indicate that the consequences of the far-right should not be considered in isolation. Specifically, while the additive term of far-right party strength remains negative and statistically significant, the interaction between this variable and citizenship is positive and highly statistically significant. This indicates that while the presence of electorally strong far-right parties is associated with lower levels of democracy satisfaction among foreign-born individuals, this negative relationship is less pronounced among those who have citizenship in their country of residence.

One shortcoming of the ESS data is that while it allows us to identify respondents' citizenship and nativity status, it does not tell us how foreigners who report having citizenship in their host country have acquired it. This means that we cannot clearly distinguish between foreign-born individuals who became citizens through naturalization and those who were born abroad but acquired citizenship in other ways (for example, inherited it from one of their parents). Hence, we were interested in whether the results remain the same when estimating the analyses against a reduced sample of foreign-born individuals whose both parents are foreign-born - that is, individuals who were more likely to acquire citizenship through naturalization. ${ }^{18}$ The results reported in Table 2 (right side) reveal that our findings remain essentially unchanged: we still find that the strength of far-right parties in national elections is associated with less sanguine evaluations of regime performance among foreign-born individuals, but this negative effect is considerably weaker among those who hold citizenship of their host country. ${ }^{19}$

The results with respect to control variables reveal that democracy satisfaction among first-generation immigrants is shaped by many factors found to be important determinants of legitimacy beliefs among natives. Specifically, identification with the ruling party, right-wing orientations, and more optimistic evaluations of the macro-economy contribute positively to democracy satisfaction, while feeling discriminated against has the opposite effect. Moreover, male and married respondents are more satisfied with democracy than women and unmarried individuals, while extreme ideological views, education, income, manual skills, and age have no detectable consequences for political system support among first-generation immigrants. ${ }^{20}$

With respect to immigrant-specific experiences, the results show that foreigners who arrived more recently are satisfied with democracy more than those who settled in their host country a long time ago. Interestingly, foreigners who are citizens of other EU countries are no different from third-country nationals. ${ }^{21}$ However, political socialization in one's country of origin does leave a mark, as newcomers from more democratic regimes are significantly more critical of the political system in their country of residence than foreigners with little exposure to democratic governance prior to migration. With respect to immigrants' experiences in their host countries, our results reveal no evidence that multiculturalism policies are related to immigrants' democracy satisfaction. ${ }^{22}$ However, the extent to which immigrants enjoy comparable opportunities as nationals to participate in their host country's political life does matter: we find that having more rights to engage politically is associated with more critical opinions about the functioning of the political system. ${ }^{23}$ Finally, democracy satisfaction among natives is positively and statistically significantly related to democracy satisfaction, suggesting that foreignborn individuals are sensitive to what natives think about the political system in their country. However, opinion climates towards immigrants among natives are statistically insignificant in all our models, highlighting the importance of electoral rather than social context in shaping democracy satisfaction among foreign-born individuals. ${ }^{24}$

How much do our key variables matter in substantive terms? Figure 1 presents the predicted values of democracy satisfaction at the maximum and minimum values of vote shares received by far-right parties in our sample of countries (using the results from the interaction model of foreign-born individuals with at least one foreign-born parent in Table 2). ${ }^{25}$ The white bars indicate system support among foreign-born non-citizens and the gray bars among foreign-born citizens, while vertical lines denote the $95 \%$ confidence intervals.

The figure reveals that far-right party strength in national legislative elections indeed plays an important role in shaping democracy satisfaction among foreign-born individuals. Specifically, the score of democracy satisfaction is reduced by 0.52 points (from 6.475 to 5.953 on a scale from 0 to 10) when we compare foreign-born noncitizens in a country with no electorally viable far-right party ( $0 \%$ votes) to a country where the far-right enjoys the highest level of electoral support in our sample of countries $-29.4 \%$ of the national vote (the Swiss People's Party in the 2007 Swiss national elections). In contrast, this gap is considerably smaller for foreign-born citizens: while the predicted value of democracy satisfaction for a foreignborn citizen living in a country with electorally weak farright parties is 6.229 , the score for a similar individual in a country with strong far-right parties is 6.198 - a difference of only 0.03 (and statistically insignificant). ${ }^{26}$ Taken together, the results confirm that national electoral support for far-right parties is indeed linked to lower levels of democracy satisfaction among foreign-born individuals, but this relationship is limited to foreign-born non-citizens.

To further assess the substantive and statistical significance of our main variables, Figure 2 reports the marginal effects of vote shares received by the far-right on democracy satisfaction among foreign-born citizens and foreignborn non-citizens (with $95 \%$ confidence intervals). In line with our expectations, the marginal effect of far-right vote shares for non-citizens is negative and statistically distinguishable from 0 , while the marginal effect for foreign- 


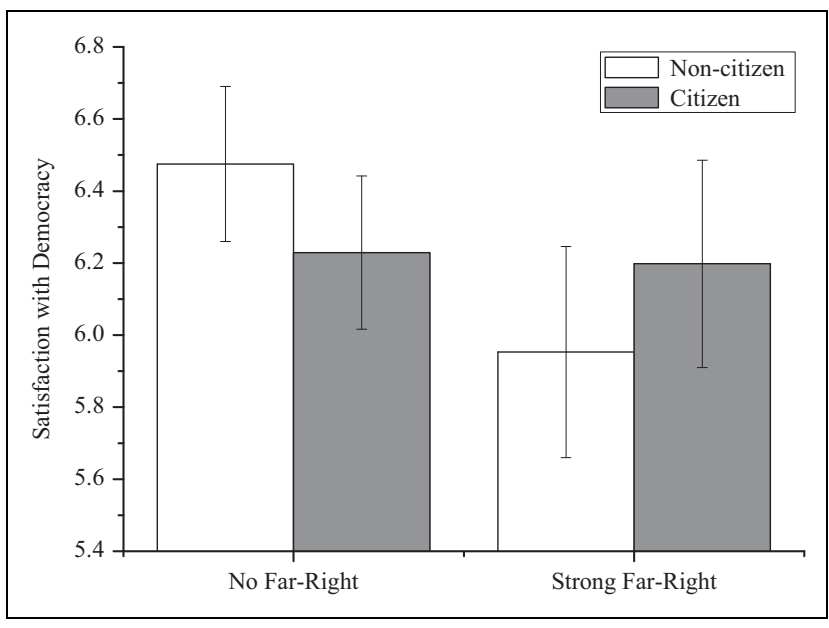

Figure I. Predicted effects of citizenship and far-right vote shares on satisfaction with democracy among foreign-born individuals, 2002-20I2.

Note: Vertical lines indicate $95 \%$ confidence intervals.

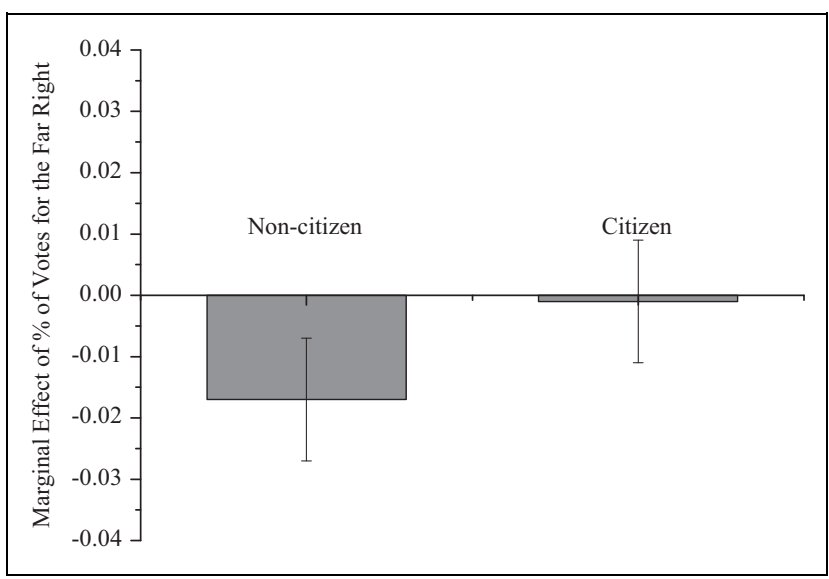

Figure2. Marginal effect of citizenship and far-right vote shares on satisfaction with democracy among foreign-born individuals, 2002-20I2.

Note: Vertical lines indicate $95 \%$ confidence intervals.

born citizens is both substantively and statistically insignificant. Specifically, the results reveal that one percent change in vote share of far-right parties is associated with a 0.017 decrease in democracy satisfaction score for a foreign-born non-citizen. ${ }^{27}$

The magnitude of the relationship between the far-right electoral strength and democracy satisfaction among foreign-born non-citizens exceeds the effects of some traditional political predictors of peoples' legitimacy beliefs, such as winning an election or holding right-wing ideological views. For instance, if we compare the scores of democracy satisfaction of respondents who feel close to a party in government and those who do not, the difference is 0.46 (in comparison to 0.52 point difference when we compare foreign-born non-citizens in countries with $0 \%$ and $29 \%$ vote share for the far-right). Similarly, moving from 0 to
10 on the left-right self-placement scale (where 0 indicates extreme left and 10 denotes extreme right) increases the score of democracy satisfaction by 0.47 - a change that is smaller than the above mentioned far-right effect. In short, the results of our analyses confirm that the extent to which far-right parties succeed in gaining votes and seats in national legislative elections is indeed strongly linked to first-generation immigrants' satisfaction with the way democracy works in their host country, but this relationship is limited to those among them who do not hold their host country's citizenship.

\section{Discussion}

The prospects of democratic legitimacy in Europe will increasingly depend on the attitudes and behavior of immigrants whose shares in contemporary democracies have been on the rise and are expected to grow in the future (e.g. de Haas, 2007). To better understand how immigrants form opinions about the political system in their adopted homeland, this study focused on foreign-born individuals in Western Europe and sought to answer several important but previously unanswered questions: do far-right parties play a role in shaping newcomers' satisfaction with the way democracy works in their host country? If so, are all foreign-born individuals equally affected by the electoral fortunes of far-right parties, or are some immigrants more sensitive to the far-right than other immigrants?

This paper argues that a comprehensive explanation of democracy satisfaction among foreign-born individuals requires taking into account not only traditional predictors of people's attitudes towards the political system, but also immigrant-specific experiences. Among these, we highlight the importance of citizenship status and far-right strength in national legislative elections of immigrant's receiving country. Our analysis reveals that the far-right vote/seat shares secured in these elections are indeed powerfully linked to democracy satisfaction among foreign-born individuals, but only among those who have not acquired citizenship of their adopted homeland. ${ }^{28}$ Interestingly, this relationship is stronger than the substantive impact of some traditional predictors of people's legitimacy beliefs, such as feeling close to a party in government or holding right-wing views. Hence, the results confirm that foreign-born non-citizens are sensitive to their host country's political context when expressing their satisfaction with the way democracy works. However, the results also show that what foreign-born non-citizens pay attention to is the electoral success of the far-right, not opinion climates towards immigrants more generally, as we find no statistically significant results with respect to anti-immigrant attitudes among natives.

Taken together, these findings challenge the conclusions of recent scholarship that far-right parties have a limited effect on politics in Western Europe (Mudde, 2013), as 
no previous studies have examined the effects of the farright in shaping democracy satisfaction among foreignborn individuals. Moreover, our findings have important implications for current debates on the political consequences of citizenship. We find that, in spite of diminishing differences between citizens and non-citizens in many contemporary democracies that now provide various legal, socio-economic, and political rights to all individuals with legal residence in their host countries (Hollifield, 1992; Jacobson, 1996; Soysal, 1994), citizenship remains an important marker of immigrants' legitimacy beliefs. We posit, although cannot test directly, that citizenship moderates the negative effect of the far-right on democracy satisfaction among foreign-born individuals for a number of reasons. Instrumentally, citizenship shields immigrants from the negative consequences of the policies of the farright by giving newcomers formal rights and protections that alleviate immigrants' threat perceptions. Furthermore, formal membership in a host society enhances immigrants' sense of political empowerment by providing them with a legal right to vote in national elections. Symbolically, citizenship strengthens immigrants' psychological attachment to their host country, lowering their support for further migration and weakening their opposition to far-right policies. As a consequence, while the electoral fortunes of far-right parties are powerfully linked to democracy satisfaction among foreign-born non-citizens, they do not significantly alter legitimacy beliefs of foreign-born individuals who have acquired citizenship in their host country.

These findings are important because electoral support for the far-right appears to be firmly rooted in European societies with a prospect to grow and enable far-right parties to become government coalition partners in the years to come (Mudde, 2013: 15-16). This suggests that favorable conditions for developing immigrants' support for democratic governance in contemporary democracies might become even harder to come by. Existing research shows that foreign-born individuals arrive with highly positive opinions about their host countries, but this optimism tends to weaken with more exposure to their adopted homelands (Maxwell, 2010; Röder and Mühlau, 2011, 2012). Our findings suggest that the rise of the far-right in many established democracies may be in part responsible for this decline, and future research could illuminate in more detail how immigrants respond to the far-right over time (and across immigrant generations). Moreover, while our study focused on the electoral strength of far-right parties at the national level, focusing on their electoral fortunes on the regional level may provide additional insights into how the far-right shapes immigrants' political attitudes and behavior. In the meantime, we conclude that while governments of immigrant receiving countries have little influence over immigrants' exposure to democratic governance in their countries of origin, they are not completely powerless in shaping the prospects of democratic legitimacy within their country borders: educating the general public about the dangers of the far-right rather than adopting their strategies in self-interested pursuit of electoral fortunes might be a good place to start.

\section{Appendix \\ Measures and coding}

Satisfaction with democracy (dependent variable). "On the whole, how satisfied are you with the way democracy works in [country]?" 0 'extremely dissatisfied', 10 'extremely satisfied'.

Foreign-born immigrant. "Were you born in [country]?" 0 'yes', 1 'no'. Foreign-born respondents with both native-born parents were excluded from the analyses.

Far-right party strength. Two indicators: \% of votes and $\%$ of seats received by far-right parties in national legislative elections. See the table below for detailed information on far-right parties by country and survey round.

Citizen. "Are you a citizen of [country]?" 1 'yes', 0 'no'. Feeling close to government party. Based on two survey questions: "Is there a particular political party you feel closer to than all the other parties?" If the answer was 'yes', then a respondent was presented with a follow up question: "Which one?" Individual responses to these questions were then matched with information from the European Journal of Political Research on government composition at the time of the survey to create a dichotomous variable, where 1 indicates that a respondent feels close to a party in government, and 0 otherwise.

Left-Right self-placement. "In politics people sometimes talk of 'left' and 'right'. Using this card, where would you place yourself on this scale, where 0 means the left and 10 means the right?"

Left-Right extremism. Absolute distance between respondent's left-right self-placement and country median (calculated for each survey round); ranges from 0 to 5 , with higher values indicating more extreme positions.

Economic evaluations. "On the whole, how satisfied are you with the present state of the economy in [country]?" 0 'extremely dissatisfied', 10 'extremely satisfied'.

Discriminated against. "Would you describe yourself as being a member of a group that is discriminated against in this country?" 1 'yes', 0 'no'.

Recent arrival. "How long ago did you first come to live in [country]?" 5 'within last year', 4 '1-5 years ago', 3 '6-10 years ago', 2 '11-20 years ago', 1 'more than 20 years ago'. 
Democracy in origin country. Based on survey questions: "Were you born in [country]?" If a respondent said "no", then the follow up question was "In which country were you born?" and "How long ago did you first come to live in [country]?" Information about immigrant country of origin and the recency of immigrant arrival were then matched up with the polity scores from the Polity IV data set http://www.cidcm.umd.edu/polity/. Since recency of immigrant arrival is a categorical variable that captures only approximate number of years in host country, the variable was calculated in the following way: if a survey was conducted in 2002, then those who arrived more than 20 years ago were assigned the average value of the 1972 1981 polity score in their country of origin, those who arrived 11-20 years ago the 1982-1991 score, those who arrived 6-10 years ago the 1992-1996 score, those who arrived 1-5 years ago the 19972001 score, and those who arrived within the last year the 2002 score. We then calculated values separately for respondents interviewed in 2003, 2004 , etc. This resulting variable ranges from 0 'least democratic regime' to 20 'most democratic regime' (recoded from the original polity measure that ranges from -10 to 10$)$.

Foreign-born but EU citizen. Respondents were first asked: "Were you born in [country]?" and "Are you a citizen of [country]?" If a respondent said 'No' to both questions, then the follow up question was "What citizenship do you hold?" If a respondent reported being a citizen of a country that was an EU member state at the time of the survey, then the variable received a value of 1 ; otherwise 0 .

Education. The highest level of education achieved; ranges from 0 to 5 , with higher values indicating a more advanced level of education achieved.

Income. "Which of the descriptions on this card comes closest to how you feel about your household's income nowadays?" 0 "very difficult on present income', 1 'difficult on present income', 2 'coping on present income', 3 'living comfortably on present income'.

Manual skills. Following Hainmueller and Hiscox (2007), coded using the ISCO88 classification: a dichotomous variable, where 1 represents 1 st and 2nd skill level (manual labor) and 0 represents 3rd and 4th skill level (skilled labor), in addition to the fifth category of legislators, senior officials, and managers assumed to be skilled.

Age. Number of years, calculated by subtracting respondent's year of birth from the year of interview.

Male. 1 'male', 0 'female'.

Married. 1 'married', 0 'otherwise'.
Speaks host country's official language at home. Respondents were asked "What language or languages do you speak most often at home?" and were given an opportunity to mention two languages. If at least one of the mentioned languages is an official language of his or her host country (as classified by the CIA), then the variable was given a value of $1 ; 0$ otherwise.

Multiculturalism policies. Immigrant multiculturalism policies from Banting and Kymlicka (2006). The indicator captures the extent to which a country's policies are designed to recognize and accommodate immigrants by taking into account 1) constitutional, legislative, or parliamentary affirmation of multiculturalism at the central and/or regional and municipal levels; 2) the adoption of multiculturalism in the school curriculum; 3) the inclusion of ethnic representation/sensitivity in the mandate of public media or media licensing; 4) exemptions from dress codes, Sunday closing legislation, etc. (either by statute or by court cases); 5) allowing dual citizenship; 6) the funding of ethnic group organizations to support cultural activities; 7) the funding of bilingual education or mothertongue instruction; 8) affirmative action for disadvantaged immigrant groups. For each of these items, a country received a score of 1.0 if it had explicitly adopted and implemented the policy; 0.5 if it adopted the policy in an implicit, incomplete, or token manner; and 0 if it did not have the policy. The resulting additive index ranges from 0 to 8 , with higher values representing stronger multiculturalism policies in a country.

Political participation rights for immigrants. Source: The Migrant Integration Policy Index (MIPEX). The measure captures the extent to which legally resident foreign citizens have comparable opportunities as nationals to participate in their host country's political life by taking into account 1) electoral rights (right to vote in national, regional, and local elections; right to stand in local elections); 2) political liberties (right to association and membership in political parties); 3) consultative bodies (presence of strong and independent advisory bodies composed of migrant representatives or associations); and 4) implementation policies (public funding and other types of government support for immigrants at national, regional, or local level). The index ranges from 0 to 100 , with higher values indicating more favorable environments for immigrant political participation.

Regional democracy satisfaction among natives. Mean democracy satisfaction score among native-born individuals whose both parents are native born. Regions within countries identified 
using ESS region variables that were based on the Nomenclature of the Statistical Territorial Units (NUTS) (cf. Maxwell, 2013).

Regional pro-immigrant attitudes among natives. Based on three survey questions: 1) "Would you say it is generally bad or good for [country's] economy that people come to live here from other countries?" 2) "Would you say that [country's] cultural life is generally undermined or enriched by people coming to live here from other countries? 3) "Is [country] made a worse or a better place to live by people coming to live here from other countries?" (Each item ranges from 0 'most anti-immigrant attitude' to 10 'most pro-immigrant' attitude.) An average based on these three items for each respondent was used to calculate the regional mean (for each ESS round) among nativeborn individuals whose both parents are native born. Regions within countries identified using ESS region variables that were based on the Nomenclature of the Statistical Territorial Units (NUTS) (cf. Maxwell, 2013).

Table A. Far-right parties used in the study.

\begin{tabular}{|c|c|c|c|c|c|c|}
\hline Country & ESS Round & Election date & $\begin{array}{l}\text { Start of ESS } \\
\text { fieldwork }\end{array}$ & $\begin{array}{l}\text { \% Far-Right } \\
\text { Votes }\end{array}$ & $\begin{array}{l}\text { \% Far-Right } \\
\text { Seats }\end{array}$ & Far-Right Parties \\
\hline Austria & I & Nov 2002 & Feb 2003 & $10.0 \%$ & $9.8 \%$ & Austrian Freedom Party (FPÖ) \\
\hline Austria & 2 & Nov 2002 & Jan 2005 & $10.0 \%$ & $9.8 \%$ & Austrian Freedom Party (FPÖ) \\
\hline Austria & 3 & Oct 2006 & Jul 2007 & $11.0 \%$ & $11.5 \%$ & Austrian Freedom Party (FPÖ) \\
\hline Austria & 4 & - & - & - & - & - \\
\hline Austria & 5 & - & - & - & - & - \\
\hline \multirow[t]{3}{*}{ Belgium } & I & Jun 1999 & Jan 2002 & $1.5 \%$ & $0.7 \%$ & National Front (FNb) \\
\hline & & & & $9.9 \%$ & $10.0 \%$ & Flemish Block (VB) \\
\hline & & & & Total: II.4\% & Total: $10.7 \%$ & \\
\hline \multirow[t]{3}{*}{ Belgium } & 2 & May 2003 & Oct 2004 & $2.0 \%$ & $0.7 \%$ & National Front (FNb) \\
\hline & & & & $11.7 \%$ & $12.0 \%$ & Flemish Block (VB) \\
\hline & & & & Total: $13.7 \%$ & Total: $12.7 \%$ & \\
\hline \multirow[t]{3}{*}{ Belgium } & 3 & May 2003 & Oct 2006 & $2.0 \%$ & $0.7 \%$ & National Front (FNb) \\
\hline & & & & $11.7 \%$ & $12.0 \%$ & Flemish Block (VB) \\
\hline & & & & Total: $13.7 \%$ & Total: $12.7 \%$ & \\
\hline \multirow[t]{3}{*}{ Belgium } & 4 & Jun 2007 & Nov 2008 & $2.0 \%$ & $0.7 \%$ & National Front (FNb) \\
\hline & & & & $12.0 \%$ & $11.3 \%$ & Flemish Interest (VB) \\
\hline & & & & Total: $14.0 \%$ & Total: $12.0 \%$ & \\
\hline \multirow[t]{3}{*}{ Belgium } & 5 & Jun 2010 & Oct 2010 & $0.5 \%$ & $0 \%$ & National Front (FNb) \\
\hline & & & & $7.8 \%$ & $8.0 \%$ & Flemish Interest (VB) \\
\hline & & & & Total: $8.3 \%$ & Total: $8.0 \%$ & \\
\hline Denmark & 1 & Nov 2001 & Jan 2002 & $12.4 \%$ & $12.6 \%$ & Danish People's Party (DF) \\
\hline Denmark & 2 & Nov 2001 & Oct 2004 & $12.4 \%$ & $12.6 \%$ & Danish People's Party (DF) \\
\hline Denmark & 3 & Feb 2005 & Sep 2006 & $13.3 \%$ & $13.7 \%$ & Danish People's Party (DF) \\
\hline Denmark & 4 & Nov 2007 & Sep 2008 & $13.9 \%$ & $14.3 \%$ & Danish People's Party (DF) \\
\hline Denmark & 5 & Nov 2007 & Oct 2010 & $13.9 \%$ & $14.3 \%$ & Danish People's Party (DF) \\
\hline Finland & 1 & Mar 1999 & Sep 2002 & $1.0 \%$ & $0.5 \%$ & True Finns (PS) \\
\hline Finland & 2 & Mar 2003 & Sep 2004 & $1.6 \%$ & $1.5 \%$ & True Finns (PS) \\
\hline Finland & 3 & Mar 2003 & Sep 2006 & $1.6 \%$ & $1.5 \%$ & True Finns (PS) \\
\hline Finland & 4 & Mar 2007 & Sep 2008 & $4.1 \%$ & $2.5 \%$ & True Finns (PS) \\
\hline Finland & 5 & Mar 2007 & Sep 2010 & $4.1 \%$ & $2.5 \%$ & True Finns (PS) \\
\hline \multirow[t]{3}{*}{ France } & 1 & Jun 2002 & Sep 2003 & $1 \mathrm{I} .1 \%$ & $0 \%$ & National Front (FN) \\
\hline & & & & $1.3 \%$ & $0 \%$ & Republican National Movement (MNR) \\
\hline & & & & Total: $12.4 \%$ & Total: $0 \%$ & \\
\hline \multirow[t]{3}{*}{ France } & 2 & Jun 2002 & Nov 2004 & $11.1 \%$ & $0 \%$ & National Front (FN) \\
\hline & & & & $1.3 \%$ & $0 \%$ & Republican National Movement (MNR) \\
\hline & & & & Total: $12.4 \%$ & Total: $0 \%$ & \\
\hline \multirow[t]{3}{*}{ France } & 3 & Jun 2002 & Sep 2006 & $11.1 \%$ & $0 \%$ & National Front (FN) \\
\hline & & & & $1.3 \%$ & $0 \%$ & Republican National Movement (MNR) \\
\hline & & & & Total: $12.4 \%$ & Total: $0 \%$ & \\
\hline
\end{tabular}


Table A. (continued)

\begin{tabular}{|c|c|c|c|c|c|c|}
\hline Country & ESS Round & Election date & $\begin{array}{l}\text { Start of ESS } \\
\text { fieldwork }\end{array}$ & $\begin{array}{l}\% \text { Far-Right } \\
\text { Votes }\end{array}$ & $\begin{array}{l}\% \text { Far-Right } \\
\text { Seats }\end{array}$ & Far-Right Parties \\
\hline \multirow[t]{3}{*}{ France } & 4 & Jun 2007 & Sep 2008 & $4.3 \%$ & $0 \%$ & National Front (FN) \\
\hline & & & & $0.4 \%$ & $0 \%$ & Republican National Movement (MNR) \\
\hline & & & & Total: $4.7 \%$ & Total: $0 \%$ & \\
\hline \multirow[t]{3}{*}{ France } & 5 & Jun 2007 & Oct 2010 & $4.3 \%$ & $0 \%$ & National Front (FN) \\
\hline & & & & $0.4 \%$ & $0 \%$ & Republican National Movement (MNR) \\
\hline & & & & Total: $4.7 \%$ & Total: $0 \%$ & \\
\hline \multirow[t]{4}{*}{ Germany } & I & Sep 2002 & Nov 2002 & $0.6 \%$ & $0 \%$ & Republican Party (REP) \\
\hline & & & & $0.4 \%$ & $0 \%$ & National Democratic Party (NPD) \\
\hline & & & & $0.3 \%$ & $0 \%$ & Law and Order Offensive Party \\
\hline & & & & Total: $1.3 \%$ & Total: $0 \%$ & \\
\hline \multirow[t]{4}{*}{ Germany } & 2 & Sep 2002 & Aug 2004 & $0.6 \%$ & $0 \%$ & Republican Party (REP) \\
\hline & & & & $0.4 \%$ & $0 \%$ & National Democratic Party (NPD) \\
\hline & & & & $0.3 \%$ & $0 \%$ & Law and Order Offensive Party \\
\hline & & & & Total: $1.3 \%$ & Total: $0 \%$ & \\
\hline \multirow[t]{3}{*}{ Germany } & 3 & Sep 2005 & Sep 2006 & $0.6 \%$ & $0 \%$ & Republican Party (REP) \\
\hline & & & & $1.6 \%$ & $0 \%$ & National Democratic Party (NPD) \\
\hline & & & & Total: $2.2 \%$ & Total: $0 \%$ & \\
\hline \multirow[t]{3}{*}{ Germany } & 4 & Sep 2005 & Aug 2008 & $0.6 \%$ & $0 \%$ & Republican Party (REP) \\
\hline & & & & $1.6 \%$ & $0 \%$ & National Democratic Party (NPD) \\
\hline & & & & Total: $2.2 \%$ & Total: $0 \%$ & \\
\hline \multirow[t]{4}{*}{ Germany } & 5 & Sep 2009 & Sep 2010 & $0.4 \%$ & $0 \%$ & Republican Party (REP) \\
\hline & & & & $0.1 \%$ & $0 \%$ & German People's Union (DVU) \\
\hline & & & & $1.5 \%$ & $0 \%$ & National Democratic Party (NPD) \\
\hline & & & & Total: $2.0 \%$ & Total: $0 \%$ & \\
\hline Greece & I & Apr 2000 & Feb 2003 & $0 \%$ & $0 \%$ & - \\
\hline Greece & 2 & Mar 2004 & Jan 2005 & $2.2 \%$ & $0 \%$ & Popular Orthodox Rally (LAOS) \\
\hline Greece & 3 & - & - & - & - & - \\
\hline Greece & 4 & Sep 2007 & Jul 2009 & $3.8 \%$ & $3.3 \%$ & Popular Orthodox Rally (LAOS) \\
\hline \multirow[t]{3}{*}{ Greece } & 5 & Oct 2009 & May 201I & $5.6 \%$ & $5.0 \%$ & Popular Orthodox Rally (LAOS) \\
\hline & & & & $0.3 \%$ & $0 \%$ & Golden Dawn \\
\hline & & & & Total: $5.9 \%$ & Total: $5.0 \%$ & \\
\hline Ireland & I & May 2002 & Dec 2002 & $0 \%$ & $0 \%$ & - \\
\hline Ireland & 2 & May 2002 & Jan 2005 & $0 \%$ & $0 \%$ & - \\
\hline Ireland & 3 & May 2002 & Jan 2006 & $0 \%$ & $0 \%$ & - \\
\hline Ireland & 4 & May 2007 & Sep 2009 & $0.1 \%$ & $0 \%$ & Immigration Control Platform (ICP) \\
\hline Ireland & 5 & Feb 20II & Aug 201 I & $0 \%$ & $0 \%$ & - \\
\hline \multirow[t]{4}{*}{ Italy } & 1 & May 200I & Jan 2003 & $3.9 \%$ & $4.9 \%$ & North League (LN) \\
\hline & & & & $0.4 \%$ & $0 \%$ & $\begin{array}{l}\text { Social Movement-Tricolour Flame } \\
\text { (MS-FT) }\end{array}$ \\
\hline & & & & $12 \%$ & $16.1 \%$ & National Alliance (AN) \\
\hline & & & & Total: $16.3 \%$ & Total: $21.0 \%$ & \\
\hline \multirow[t]{4}{*}{ Italy } & 2 & May 2001 & Feb 2006 & $3.9 \%$ & $4.9 \%$ & North League (LN) \\
\hline & & & & $0.4 \%$ & $0 \%$ & $\begin{array}{l}\text { Social Movement-Tricolour Flame } \\
\quad(\text { MS-FT) }\end{array}$ \\
\hline & & & & $12 \%$ & $16.1 \%$ & National Alliance (AN) \\
\hline & & & & Total: $16.3 \%$ & Total: $21.0 \%$ & \\
\hline Italy & 3 & - & - & - & - & - \\
\hline Italy & 4 & - & - & - & - & - \\
\hline Italy & 5 & - & - & - & - & - \\
\hline Netherlands & 1 & May 2002 & Sep 2002 & $17.0 \%$ & $17.3 \%$ & List Pim Fortuyn Party (LPF) \\
\hline Netherlands & 2 & Jan 2003 & Sep 2004 & $5.6 \%$ & $5.3 \%$ & List Pim Fortuyn Party (LPF) \\
\hline
\end{tabular}


Table A. (continued)

\begin{tabular}{|c|c|c|c|c|c|c|}
\hline Country & ESS Round & Election date & $\begin{array}{l}\text { Start of ESS } \\
\text { fieldwork }\end{array}$ & $\begin{array}{c}\% \text { Far-Right } \\
\text { Votes }\end{array}$ & $\begin{array}{l}\% \text { Far-Right } \\
\text { Seats }\end{array}$ & Far-Right Parties \\
\hline \multirow[t]{2}{*}{ Netherlands } & 3 & $\begin{array}{l}\text { Jan } 2003 \text { \& Nov } \\
2006\end{array}$ & $\begin{array}{c}\text { Sep-Dec } \\
2006\end{array}$ & $\begin{array}{l}0.6 \% \\
5.9 \%\end{array}$ & $\begin{array}{c}0 \% \\
6.0 \%\end{array}$ & $\begin{array}{l}\text { One NL } \\
\text { Party for Freedom/Group Wilders } \\
\quad \text { (PVV) }\end{array}$ \\
\hline & & & & $\begin{array}{c}0.2 \% \\
\text { Total: } 6.7 \%\end{array}$ & $\begin{array}{c}0 \% \\
\text { Total: } 6.0 \%\end{array}$ & Fortuyn \\
\hline Netherlands & 4 & Nov 2006 & Sep 2008 & $\begin{array}{c}0.6 \% \\
5.9 \% \\
0.2 \% \\
\text { Total: } 6.7 \%\end{array}$ & $\begin{array}{c}0 \% \\
6.0 \% \\
0 \% \\
\text { Total: } 6.0 \%\end{array}$ & $\begin{array}{l}\text { One NL } \\
\text { Freedom Party (PVV) } \\
\text { Fortuyn }\end{array}$ \\
\hline Netherlands & 5 & Jun 2010 & Sep 2010 & $15.5 \%$ & $16.0 \%$ & Freedom Party (PVV) \\
\hline Norway & 1 & Sep 200I & Sep 2002 & $14.6 \%$ & $15.8 \%$ & Progress Party (FRP) \\
\hline Norway & 2 & Sep 200I & Sep 2004 & $14.6 \%$ & $15.8 \%$ & Progress Party (FRP) \\
\hline Norway & 3 & Sep 2005 & Aug 2006 & $\begin{array}{c}22.1 \% \\
0.1 \% \\
\text { Total: } 22.2 \%\end{array}$ & $\begin{array}{c}22.5 \% \\
0 \% \\
\text { Total: } 22.5 \%\end{array}$ & $\begin{array}{l}\text { Progress Party (FRP) } \\
\text { The Democrats (DIN) }\end{array}$ \\
\hline Norway & 4 & Sep 2005 & Aug 2008 & $\begin{array}{c}22.1 \% \\
0.1 \% \\
\text { Total: } 22.2 \%\end{array}$ & $\begin{array}{c}22.5 \% \\
0 \% \\
\text { Total: } 22.5 \%\end{array}$ & $\begin{array}{l}\text { Progress Party (FRP) } \\
\text { The Democrats (DIN) }\end{array}$ \\
\hline Norway & 5 & Sep 2009 & Sep 2010 & $\begin{array}{c}22.9 \% \\
0.1 \% \\
\text { Total: } 23.0 \%\end{array}$ & $\begin{array}{c}24.3 \% \\
0 \% \\
\text { Total: } 24.3 \%\end{array}$ & $\begin{array}{l}\text { Progress Party (FRP) } \\
\text { The Democrats (DIN) }\end{array}$ \\
\hline Portugal & 1 & Mar 2002 & Sep 2002 & $0.1 \%$ & $0 \%$ & National Renewal Party (PNR) \\
\hline Portugal & 2 & Mar 2002 & Oct 2004 & $0.1 \%$ & $0 \%$ & National Renewal Party (PNR) \\
\hline Portugal & 3 & Feb 2005 & Oct 2006 & $0.2 \%$ & $0 \%$ & National Renewal Party (PNR) \\
\hline Portugal & 4 & Feb 2005 & Oct 2008 & $0.2 \%$ & $0 \%$ & National Renewal Party (PNR) \\
\hline Portugal & 5 & Sep 2009 & Nov 2010 & $0.2 \%$ & $0 \%$ & National Renewal Party (PNR) \\
\hline Spain & 1 & Mar 2000 & Nov 2002 & $0 \%$ & $0 \%$ & - \\
\hline Spain & 2 & Mar 2004 & Apr 2004 & $0 \%$ & $0 \%$ & - \\
\hline Spain & 3 & Mar 2004 & Oct 2006 & $0 \%$ & $0 \%$ & - \\
\hline Spain & 4 & Mar 2008 & Sep 2008 & $0 \%$ & $0 \%$ & - \\
\hline Spain & 5 & Mar 2008 & Apr 2011 & $0 \%$ & $0 \%$ & - \\
\hline Sweden & I & Sep 2002 & Oct 2002 & $1.4 \%$ & $0 \%$ & Sweden Democrats (SD) \\
\hline Sweden & 2 & Sep 2002 & Sep 2004 & $1.4 \%$ & $0 \%$ & Sweden Democrats (SD) \\
\hline Sweden & 3 & Sep 2006 & Sep 2006 & $2.9 \%$ & $0 \%$ & Sweden Democrats (SD) \\
\hline Sweden & 4 & Sep 2006 & Sep 2008 & $2.9 \%$ & $0 \%$ & Sweden Democrats (SD) \\
\hline Sweden & 5 & Sep 2010 & Oct 2010 & $5.7 \%$ & $5.7 \%$ & Sweden Democrats (SD) \\
\hline \multirow[t]{4}{*}{ Switzerland } & I & Oct 1999 & Jul 2002 & $22.6 \%$ & $22.0 \%$ & Swiss People's Party (SVP) \\
\hline & & & & $0.9 \%$ & $0 \%$ & Freedom Party (FPS) \\
\hline & & & & $1.8 \%$ & $0.5 \%$ & Swiss Democrats (SD) \\
\hline & & & & Total: $25.3 \%$ & Total: $22.5 \%$ & \\
\hline \multirow[t]{4}{*}{ Switzerland } & 2 & Oct 2003 & Sep 2004 & $26.7 \%$ & $27.5 \%$ & Swiss People's Party (SVP) \\
\hline & & & & $0.2 \%$ & $0 \%$ & Freedom Party (FPS) \\
\hline & & & & $1.0 \%$ & $0.5 \%$ & Swiss Democrats (SD) \\
\hline & & & & Total: $27.9 \%$ & Total: $28.0 \%$ & \\
\hline \multirow[t]{4}{*}{ Switzerland } & 3 & Oct 2003 & Aug 2006 & $26.7 \%$ & $27.5 \%$ & Swiss People's Party (SVP) \\
\hline & & & & $0.2 \%$ & $0 \%$ & Freedom Party (FPS) \\
\hline & & & & $1.0 \%$ & $0.5 \%$ & Swiss Democrats (SD) \\
\hline & & & & Total: $27.9 \%$ & Total: $28.0 \%$ & \\
\hline \multirow[t]{3}{*}{ Switzerland } & 4 & Oct 2007 & Aug 2008 & $28.9 \%$ & $31.0 \%$ & Swiss People's Party (SVP) \\
\hline & & & & $0.5 \%$ & $0 \%$ & Swiss Democrats (SD) \\
\hline & & & & Total: $29.4 \%$ & Total: $31.0 \%$ & \\
\hline \multirow[t]{3}{*}{ Switzerland } & 5 & Oct 2007 & Oct 2010 & $28.9 \%$ & $31.0 \%$ & Swiss People's Party (SVP) \\
\hline & & & & $0.5 \%$ & $0 \%$ & Swiss Democrats (SD) \\
\hline & & & & Total: $29.4 \%$ & Total: $31.0 \%$ & \\
\hline
\end{tabular}


Table A. (continued)

\begin{tabular}{|c|c|c|c|c|c|c|}
\hline Country & ESS Round & Election date & $\begin{array}{l}\text { Start of ESS } \\
\text { fieldwork }\end{array}$ & $\begin{array}{c}\text { \% Far-Right } \\
\text { Votes }\end{array}$ & $\begin{array}{l}\text { \% Far-Right } \\
\text { Seats }\end{array}$ & Far-Right Parties \\
\hline UK & I & Jun 200I & Sep 2002 & $0.2 \%$ & $0 \%$ & British National Party (BNP) \\
\hline UK & 2 & Jun 200I & Sep 2004 & $0.2 \%$ & $0 \%$ & British National Party (BNP) \\
\hline \multirow[t]{3}{*}{ UK } & 3 & May 2005 & Sep 2006 & $0.7 \%$ & $0 \%$ & British National Party (BNP) \\
\hline & & & & $0.1 \%$ & $0 \%$ & Veritas \\
\hline & & & & Total: $0.8 \%$ & Total: $0 \%$ & \\
\hline \multirow[t]{3}{*}{ UK } & 4 & May 2005 & Sep 2008 & $0.7 \%$ & $0 \%$ & British National Party (BNP) \\
\hline & & & & $0.1 \%$ & $0 \%$ & Veritas \\
\hline & & & & Total: $0.8 \%$ & Total: $0 \%$ & \\
\hline UK & 5 & May 2010 & Aug 201I & $1.9 \%$ & $0 \%$ & British National Party (BNP) \\
\hline
\end{tabular}

\section{Declaration of conflicting interests}

The author(s) declared no potential conflicts of interest with respect to the research, authorship, and/or publication of this article.

\section{Funding}

The author(s) received no financial support for the research, authorship, and/or publication of this article.

\section{Notes}

1. We use our key concept - satisfaction with the way democracy works in one's country of residence - interchangeably with "democracy satisfaction", "legitimacy beliefs", and "system support". Foreign-born individuals are sometimes referred to as "foreigners", "first-generation immigrants", or simply "immigrants".

2. Most existing research on far-right parties focuses on understanding the nature of their ideological appeals, organizational development, as well as the determinants of their electoral breakthrough and persistence (e.g. Arzheimer, 2009; Betz, 1993; Carter, 2005; Gibson, 2002; Givens, 2005; Golder, 2003; Ignazi, 1992, 2003; Ivarsflaten, 2005; Kitschelt and McGann, 1995; Koopmans et al., 2005, ch5; Mudde, 2000; Norris, 2005; van der Brug et al., 2005). Other scholars examine how democracies responded to the rise of the far-right by studying, for example, the behavior and policy positions of other parties (e.g. Alonso and Claro da Fonseca, 2012; Bale, 2003; Bale et al., 2010; Downs, 2012; van Spanje, 2010), policy outcomes (e.g. Akkerman, 2012; Givens and Luedtke, 2004; Koopmans et al., 2012; Minkenberg, 2001; Perlmutter, 2002; Schain, 2006, 2009), and the attitudes of native populations (e.g. Dunn and Singh, 2011; McLaren, 2012; Sprague-Jones, 2011; Wilkes et al., 2007; for a useful literature overview, see also Mudde, 2013).

3. Consistent with these findings, Mudde (2007: 26) argues that nativism - an ideology that combines nationalism and xenophobia - constitutes one of the key ideological features of radical right parties.

4. One exception is refugee policies that are decided at the level of the EU.

5. Our argument focusing on far-right parties does not deny that perceptions of threat among immigrants might stem also from other sources, for example, mainstream parties that have adopted anti-immigrant positions. However, given the importance and degree of hostility towards immigrants among far-right parties (that we document below), we believe that their success in national elections is likely to play a particularly important role in shaping immigrants' views about the functioning of democracy in their host country.

6. Moreover, existing research suggests that there is a positive relationship between instrumental and symbolic aspects of citizenship: its instrumental advantages - that is, rights, protections, and entitlements that come with citizenship acquisition - enable immigrants to develop stronger affective ties to their host society, as these advantages provide newcomers with a long-term stake in their host country's future (e.g. Maxwell and Bleich, 2014; Reeskens and Wright, 2014).

7. In line with this perspective, several previous studies on Latino immigrants in the US found that perceptions of linked fate or attachment to their in-group are much stronger among foreignborn individuals than among immigrants of later generations (e.g. Barreto and Pedraza, 2009; Sanchez and Masuoka, 2010).

8. The ESS data were collected using strict random sampling of individuals aged 15 or older regardless of citizenship, nationality, legal status, or language to ensure representativeness of national populations. They have been shown to contain representative samples of foreign-born populations as well (for details, see Just and Anderson, 2012).

9. Looking at the data reveals that only $3.5 \%$ of foreign-born citizens and $6.6 \%$ of foreign-born non-citizens gave a "don't know" response to this question, while the respective percentage among native-born citizens was $2.9 \%$.

10. To ensure that our sample contains genuine immigrants, foreign-born respondents with both native-born parents were removed from the analyses.

11. For other studies using samples of foreign-born individuals from the ESS data, see, for example, Just and Anderson (2012, 2014, 2015), Maxwell (2010), Röder and Mühlau (2012), Wright and Bloemraad (2012).

12. We have updated this list with information for the fifth round of the ESS data and have added a few minor parties that fulfil McLaren's selection criteria but were previously overlooked, 
most likely because of their small vote shares. Including these parties in our data, however, does not change our main findings and our inferences remain the same.

13. We considered using data also from the Comparative Manifesto Project (Klingemann et al., 2006) as well as the Democratic Accountability and Linkages Project (Kitschelt, 2013) as alternative sources for measuring party orientation towards the issue of immigration. Unfortunately, the Comparative Manifesto Project does not include any direct indicators of party positions on immigration (the item that comes closest is multiculturalism - a rather distant and imperfect proxy for immigration); neither does it clearly distinguish between positions and salience with respect to issues. Moreover, the Comparative Manifesto Project includes only parties that were able to secure at least two seats in the national parliament of their country, considerably reducing the number of far-right parties in the dataset. Another data source - The Democratic Accountability and Linkages Project dataset has the advantage of containing an item measuring party positions on immigration. However, data on this item are available only for three countries (Austria, Germany, and Greece) due to the fact that immigration was treated as a country-specific issue and data on this item was therefore not collected in all countries included in the project. Hence, Benoit and Laver's (2006) data is the best source to test whether the political parties we focus on are indeed more anti-immigrant because it provides indicators with respect to both salience and position on immigration, and also because it includes information on a much larger number of countries than other datasets.

14. Information is not available in Spain and Ireland because there were no far-right parties in the relevant elections of these countries; data on far-right parties is missing in Greece, Portugal, Sweden, and the UK because these parties were not included in Benoit and Laver's (2006) data, most likely because of their small vote shares and no legislative seats.

15. We operationalize natives as native-born individuals whose parents are both native-born.

16. Since we have only five survey rounds in the ESS data, the number of cases is insufficient to employ survey rounds as a separate level of analysis. We therefore rely on countryrounds as a macro-level unit of analysis, while at the same time including ESS round fixed effects. Alternative specifications, such as using countries (instead of country-rounds) as a macro-level unit of analysis or adding country dummy variables (instead of survey round dummies) to our models, does not change our main findings appreciably and our inferences remain the same.

17. Foreigners' countries of origin were nested within host country-rounds, but using crossed random intercepts produces nearly identical results.

18. Looking at the data reveals that the share of foreigners with one foreign-born parent (in comparison to two foreign-born parents) is quite small - only $9.97 \%$. Moreover, $18 \%$ of these individuals do not have citizenship of their host country. This suggests that the primary route to citizenship among our respondents is naturalization.

19. The results of additional robustness tests using all respondents in the ESS sample (that is, both native- and foreignborn) are consistent with our expectations. Moreover, estimating our models on a more restricted sample of populist radical right parties, as classified by Mudde (2007) (instead of a broader group of far-right parties) generates nearly identical results.

20. Additionally controlling for political interest does not change our main findings.

21. Excluding this variable from our models does not change our main results.

22. Using alternative indicators, such as the Migrant Integration Policy Index (MIPEX) (Niessen et al., 2007) or the Citizenship Policy Index (CPI) (Howard, 2009) does not change our main findings. Moreover, including an interaction term between far-right party strength and multiculturalism or, alternatively, between far-right party strength and naturalization policies, produces statistically insignificant results with respect to these interaction terms, while our main findings remain the same.

23. Using immigrants' electoral rights (instead of the more general measure of immigrants' political participation rights that we employ in our analyses) produces nearly identical results.

24. While our models rely on regional (subnational) measures of natives' anti-immigrant attitudes and democracy satisfaction, using country level measures or excluding these variables from the models does not affect our findings appreciably and our inferences remain the same.

25. We hold other variables at their means and dichotomous variables at their medians.

26. The results also show that in countries with no far-right parties, foreign-born non-citizens are more satisfied with democracy than foreign-born citizens, while the pattern is reversed in countries with strong far-right parties. However, since these differences are statistically insignificant, we do not comment on them further.

27. As before, other variables are held at their means, and dichotomous variables at their medians.

28. The link between far-right party strength and democracy satisfaction is negative and statistically significant also among native-born individuals. While comparing natives and foreign-born individuals is beyond the scope of our study, it may be a fruitful venue for future research.

\section{References}

Akkerman T (2012) Comparing radical right parties in government: Immigration and integration policies in nine countries (1996-2010). West European Politics 35(3): 511-529.

Almond GA and Verba S (1963) The Civic Culture. Boston, MA: Little, Brown and Company.

Alonso S and Claro da Fonseca S (2012) Immigration, left and right. Party Politics 18(6): 865-884. 
Anderson CJ and Guillory CA (1997) Political institutions and satisfaction with democracy: A cross-national analysis of consensus and majoritarian systems. American Political Science Review 91(1): 66-82.

Anderson CJ and Singer MM (2008) The sensitive left and the impervious right. Comparative Political Studies 41(4-5): 564-599.

Anderson CJ, Blais A, Bowler S, et al. (2005) Losers' Consent: Elections and Democratic Legitimacy. Oxford: Oxford University Press.

Arzheimer K (2009) Contextual factors and the extreme right vote in Western Europe, 1980-2002. American Journal of Political Science 53(2): 259-275.

Bale T (2003) Cinderella and her ugly sisters: The mainstream and extreme right in Europe's bipolarising party systems. West European Politics 26(3): 67-90.

Bale T (2008) Politics matters: A conclusion. Journal of European Public Policy 15(3): 453-464.

Bale T, Green-Pedersen C, Krouwel A, et al. (2010) If you can't beat them, join them? Explaining social democratic responses to the challenge from the populist radical right in Western Europe. Political Studies 58(3): 410-426.

Banting K and Kymlicka W (eds) (2006) Multiculturalism and the Welfare State: Recognition and Redistribution in Contemporary Democracies. Oxford: Oxford University Press.

Barreto MA and Pedraza FI (2009) The renewal and persistence of group identification in American politics. Electoral Studies 28(4): 595-605.

Bauböck R (2007) Migration and Citizenship: Legal Status, Rights and Political Participation. Amsterdam: Amsterdam University Press.

Benoit K and Laver M (2006) Party Policy in Modern Democracies. London: Routledge.

Betz H-G (1993) The new politics of resentment: Radical rightwing populist parties in Western Europe. Comparative Politics 25(4): 413-427.

Bloemraad I, Korteweg A and Yurdakul G (2008) Citizenship and immigration: Multiculturalism, assimilation, and challenges to the nation-state. Annual Review of Sociology 34: 153-179.

Carter E (2005) The Extreme Right in Western Europe: Success or Failure? Manchester: Manchester University Press.

Cho WKT, Gimpel JG and Wu T (2006) Clarifying the role of SES in political participation: Policy threat and Arab American mobilization. Journal of Politics 68(4): 977-991.

Clarke HD, Dutt N and Kornberg A (1993) The political economy of attitudes toward policy and society in Western European democracies. Journal of Politics 55(4): 998-1021.

Cooley CH (1956) Human Nature and the Social Order. New York, NY: Scribner.

Dalton RJ (2004) Democratic Challenges, Democratic Choices: The Erosion of Political Support in Advanced Industrial Democracies. Oxford: Oxford University Press.

de Haas H (2007) Turning the tide? Why development will not stop migration. Development and Change 38(5): 819-841.
Downs WM (2012) Political Extremism in Democracies: Combating Intolerance. New York, NY: Palgrave Macmillan.

Dunn KP and Singh SP (2011) The surprising non-impact of radical right-wing populist party representation on public tolerance of minorities. Journal of Elections, Public Opinion and Parties 21(3): 313-331.

Frable DES (1997) Gender, racial, ethnic, sexual, and class identities. Annual Review of Psychology 48(1): 139-162.

Fuchs D, Guidorossi G and Svenson P (1995) Support for the democratic system. In: Klingemann HD and Fuchs D (eds) Citizens and the State. Oxford: Oxford University Press, 323-353.

Gibson RK (2002) The Growth of Anti-Immigrant Parties in Western Europe. Lewiston: Edwin Mellen Press.

Ginsberg B and Weissberg R (1978) Elections and the mobilization of popular support. American Journal of Political Science 22(1): 31-55.

Givens TE (2005) Voting Radical Right in Western Europe. Cambridge: Cambridge University Press.

Givens T and Luedtke A (2004) The politics of European union immigration policy: Institutions, salience and harmonization. Policy Studies Journal 32(1): 145-165.

Golder M (2003) Explaining variation in the success of extreme right parties in Western Europe. Comparative Political Studies 36(4): 432-466.

Hainmueller J and Hiscox MJ (2007) Educated preferences: Explaining attitudes toward immigration in Europe. International Organization 61(2): 399-442.

Hall JA and Briton NJ (1993) Gender, nonverbal behavior, and expectations. In: Blanck PD (ed.) Interpersonal Expectations: Theory, Research, and Applications. New York, NY: Cambridge University Press.

Hetherington MJ (1998) The political relevance of political trust. American Political Science Review 92(4): 791-808.

Hochschild JL and Mollenkopf JH (eds) (2009) Bringing Outsiders In: Transatlantic Perspectives on Immigrant Political Incorporation. Ithaca, NY: Cornell University Press.

Hollifield JF (1992) Immigrants, Markets, and States: The Political Economy of Postwar Europe. Cambridge, MA: Harvard University Press.

Howard MM (2009) The Politics of Citizenship in Europe. Cambridge: Cambridge University Press.

Ignazi P (1992) The silent counter-revolution: Hypotheses on the emergence of right-wing parties in Europe. European Journal of Political Research 22(1): 3-34.

Ignazi P (2003) Extreme Right Parties in Western Europe. Oxford: Oxford University Press.

Ivarsflaten E (2005) The vulnerable populist right parties: No economic realignment fueling their electoral success. European Journal of Political Research 44(3): 465-492.

Ivarsflaten E (2008) What unites right-wing populists in Western Europe? Re-examining grievance mobilization models in seven successful cases. Comparative Political Studies 41(1): $3-23$. 
Jacobs D (1999) The debate over enfranchisement of foreign residents in Belgium. Journal of Ethnic and Migration Studies 25(4): 649-663.

Jacobson D (1996) Rights across Borders: Immigration and the Decline of Citizenship. Baltimore, MD: Johns Hopkins University Press.

Joppke C (2007a) Transformation of immigrant integration: Civic integration and antidiscrimination in the Netherlands, France, and Germany. World Politics 59(2): 243-273.

Joppke C (2007b) Beyond national models: Civic integration policies for immigrants in Western Europe. West European Politics 30(1): 1-22.

Just A and Anderson CJ (2012) Immigrants, citizenship and political action in Europe. British Journal of Political Science 42(3): 481-509.

Just A and Anderson CJ (2014) Opinion climates and immigrant political action. Comparative Political Studies 47(7): 935-965.

Just A and Anderson CJ (2015) Dual allegiances? Immigrants' attitudes towards immigration. The Journal of Politics 77(1): 188-201.

Kitschelt H (2013) Democratic Accountability and Linkages Project. Durham, NC: Duke University.

Kitschelt H and McGann A (1995) The Radical Right in Western Europe: A Comparative Analysis. Ann Arbor, MI: University of Michigan.

Kittilson MC (2009) Research resources in comparative political behavior. In: Dalton RJ and Klingemann H-D (eds) The Oxford Handbook of Political Behavior. Oxford: Oxford University Press, 865-895.

Klingemann H-D (1999) Mapping political support in the 1990s: A global analysis. In: Norris P (ed.) Critical Citizens: Global Support for Democratic Governance. Oxford: Oxford University Press, 31-56.

Klingemann H-D, Volkens A, Budge I, et al. (2006) Mapping Policy Preferences II: Estimates for Parties, Electors, and Governments in Eastern Europe, European Union, and OECD 1990-2003. New York: Oxford University Press.

Koopmans R, Michalowski I and Waibel S (2012) Citizenship rights for immigrants: National political processes and crossnational convergence in Western Europe. American Journal of Sociology 117(4): 1202-1245.

Koopmans R, Statham P, Giugni M, et al. (2005) Contested Citizenship: Immigration and Cultural Diversity in Europe. Minneapolis, MN: Minnesota University Press.

Kriesi H, Grande E, Lachat R, et al. (2008) West European Politics in the Age of Globalization. Cambridge: Cambridge University Press.

Linde J and Ekman J (2003) Satisfaction with democracy: A note on frequently used indicator in comparative politics. European Journal of Political Research 42(3): 391-408.

Lipset SM (1959) Political Man: The Social Bases of Politics. Garden City, NY: Doubleday.

McLaren LM (2012) The cultural divide in Europe: Migration, multiculturalism, and political trust. World Politics 64(2): 199-241.
Maxwell R (2010) Evaluating migrant integration: Political attitudes across generations in Europe. International Migration Review 44(1): 25-52.

Maxwell R (2013) The geographic context of political attitudes among migrant-origin individuals in Europe. World Politics 65(1): 116-155.

Maxwell R and Bleich E (2014) What makes Muslims feel French? Social Forces 93(1): 155-179.

Messina AM (2007) The Logics and Politics of Post-WWII Migration to Western Europe. Cambridge: Cambridge University Press.

Michelson MR (2001) Political trust among Chicago Latinos. Journal of Urban Affairs 23(3-4): 323-334.

Michelson MR (2003) The corrosive effects of acculturation: How Mexican Americans lose political trust. Social Science Quarterly 84(4): 918-933.

Minkenberg M (2001) The radical right in public office: Agenda-setting and policy effects. West European Politics 24(4): 1-21.

Mudde C (2000) The Ideology of the Extreme Right. Manchester: Manchester University Press.

Mudde C (2007) Populist Radical Right Parties in Europe. Cambridge: Cambridge University Press.

Mudde C (2013) Three decades of populist radical right parties in Western Europe: So what? European Journal of Political Research 52(1): 1-19.

Mutz DC (1998) Impersonal Influence: How Perceptions of Mass Collectives Affect Political Attitudes. Cambridge: Cambridge University Press.

Nadeau R and Blais A (1993) Accepting the election outcome: The effect of participation on loser's consent. British Journal of Political Science 23(4): 553-563

Niessen J, Huddleston T and Citron L (2007) Migrant Integration Policy Index. Brussels: British Council and Migration Policy Group.

Noelle-Neumann E (1974) The spiral of silence: A theory of public opinion. Journal of Communication 24(2): 43-51.

Noelle-Neumann E (1993) The Spiral of Silence: Public Opinion, Our Social Skin. 2nd ed. Chicago, IL: University of Chicago Press.

Norris P (ed.) (1999) Critical Citizens: Global Support for Democratic Government. Oxford: Oxford University Press.

Norris P (2005) Radical Right: Voters and Parties in the Electoral Market. Cambridge: Cambridge University Press.

Norris P (2011) Democratic Deficit: Critical Citizens Revisited. Cambridge: Cambridge University Press.

Oyserman D and Swim JK (2001) Stigma: An insider's view. Journal of Social Issues 57(1): 1-14.

Pantoja AD, Ramirez R and Segura GM (2001) Citizens by choice, voters by necessity: Patterns in political mobilization by naturalized Latinos. Political Research Quarterly 54(4): $729-750$.

Pérez EO (2014) Xenophobic rhetoric and its political effects on immigrants and their co-ethnics. American Journal of Political Science 59(3): 549-564. 
Perlmutter T (2002) The politics of restriction. The effect of xenophobic parties on Italian immigration policy and German asylum policy. In: Schain M, Zolberg A and Hossay $\mathrm{P}$ (eds) Shadows over Europe: The Development and Impact of the Extreme Right in Western Europe. New York, NY: Palgrave, 269-298.

Pharr SJ and Putnam RD (2000) Disaffected Democracies: What's Troubling the Trilateral Countries? Princeton, NJ: Princeton University Press.

Powell GB Jr (1982) Contemporary Democracies: Participation, Stability and Violence. Cambridge, MA: Harvard University Press.

Powell GB Jr (1986) Extremist parties and political turmoil: Two puzzles. American Journal of Political Science 30(2): 357378.

Ramakrishnan KS (2005) Democracy in Immigrant America: Changing Demographics and Political Participation. Stanford, CA: Stanford University Press.

Ramakrishnan KS and Espenshade TJ (2001) Immigrant incorporation and political participation in the United States. International Migration Review 35(3): 870-909.

Reeskens $\mathrm{T}$ and Wright M (2014) Host-country patriotism among European immigrants: A comparative study of its individual and societal roots. Ethnic and Racial Studies 37(14): 2493-2511.

Riker WH (1982) Liberalism against Populism: A Confrontation between the Theory of Democracy and the Theory of Social Choice. San Francisco, CA: W. H. Freeman.

Röder A and Mühlau P (2011) Discrimination, exclusion and immigrants' confidence in public institutions in Europe. European Societies 13(4): 535-557.

Röder A and Mühlau P (2012) Low expectations or different evaluations: What Explains immigrants' high levels of trust in host-country institutions? Journal of Ethnic and Migration Studies 38(5): 777-792.

Sanchez GR and Masuoka N (2010) Brown-utility heuristic? The presence and contributing factors of Latino linked fate. Hispanic Journal of Behavioral Sciences 32(4): 519-531.

Schain MA (2006) The extreme-right and immigration policy making: Measuring direct and indirect effects. West European Politics 29(2): 270-289.

Schain MA (2009) The state strikes back: Immigration policy in the European Union. European Journal of International Law 20(1): 93-109.

Scheufele DA and Moy P (2000) Twenty-five years of the spiral of silence: A conceptual review and empirical outlook. International Journal of Public Opinion Research 12(1): 3-28.

Simon B, Reichert F, Christoph DS, et al. (2015) Dual identification and the (de-)politicization of migrants: Longitudinal and comparative evidence. Journal of Community and Applied Social Psychology 25(3): 193-203.

Snijders TAB and Bosker R (1999) Multilevel Analysis: An Introduction to Basic and Advanced Multilevel Modeling. Thousand Oaks, CA: Sage Publications.

Soysal YN (1994) Limits of Citizenship. Migrants and Postnational Membership in Europe. Chicago, IL: Chicago University Press.

Sprague-Jones J (2011) Extreme Right-wing vote and support for multiculturalism in Europe. Racial and Ethnic Studies 34(4): 535-555.

Steenbergen MR and Jones BS (2002) Modeling multilevel data structures. American Journal of Political Science 46(1): 218-237.

Tyler TR (1990) Why People Obey the Law. New Haven, CT: Yale University Press.

van der Brug W, Fennema M and Tillie J (2005) Why some antiimmigrant parties fail and others succeed: A two-step model of aggregate electoral support. Comparative Political Studies 38(5): 537-573.

van Spanje J (2010) Contagious parties: Anti-immigration parties and their impact on other parties' stances on immigration in contemporary Western Europe. Party Politics 16(5): 563-586.

White S, Nevitte N, Blais A, et al. (2008) The political resocialization of immigrants. Political Research Quarterly 61(2): 268-281.

Wilkes R, Guppy N and Farris L (2007) Right-wing parties and anti-foreigner sentiment in Europe. American Sociological Review 72(5): 831-840.

Wright $\mathrm{M}$ and Bloemraad I (2012) Is there a trade-off between multiculturalism and socio-political integration? Policy regimes and immigrant incorporation in comparative perspective. Perspectives on Politics 10(1): 77-95.

Zaslove A (2004) Closing the door? The ideology and impact of radical right populism on immigration policy in Austria and Italy. Journal of Political Ideologies 9(1): 99-118.

\section{Author biography}

Aida Just is Associate Professor in the Department of Political Science and Public Administration at Bilkent University, Turkey. Her research interests include mass political behavior, public opinion, and political parties, especially from a cross-national perspective and with respect to the issues of democratic legitimacy, political representation, and international migration. Her recent work has appeared in the Journal of Politics, the British Journal of Political Science, Comparative Political Studies, the European Political Science Review, Electoral Studies, the Journal of Peace Research, and Social Science Research. 